Educational Research for Social Change (ERSC)

Volume: 6 No. 2, September 2017

pp. 1-15

ersc.nmmu.ac.za

ISSN: 2221-4070

\title{
A Nonviolent Pedagogical Approach for Life Orientation Teacher Development: The Alternatives to Violence Project
}

\author{
Shena Lamb \\ Nelson Mandela Metropolitan University \\ Shena.Lamb@nmmu.ac.za \\ Lyn Snodgrass \\ Nelson Mandela Metropolitan University \\ Lyn.Snodgrass@nmmu.ac.za
}

\section{Abstract}

Violence in South African schools seems to be increasing and the consequences affect not only the physical, emotional, and academic lives of learners but also their resistance to delinquent and criminal behaviour. Because the foundations for youth violence are laid in early adolescence, violence prevention in schools is a critical need. Life orientation (LO) as a compulsory school subject could play a key role in helping South African learners deal with the different manifestations of violence, especially understanding the nature of the institutionalised violence of colonialism and apartheid. LO can also nurture learners' personal development and life skills to increase their sense of agency, a key factor in both violence prevention and learners' decolonisation processes. However, various South African studies attest to the current low status of LO in the school curriculum as well as the difficulties of teaching LO. Many of these studies also mention the inadequacy of LO teachers' preparation for meaningful LO teaching. Given that equipping current-day South African learners with the self-empowerment skills necessary for preventing everyday conflicts from escalating into violence also entails this complex decolonisation process to liberate them of past or still present oppressions, this paper contends that LO teachers need to have first participated in such self-development processes themselves. For these reasons, this article proposes a specific development strategy to support LO teachers, namely, that they participate in workshops of the Alternatives to Violence Project (AVP), ${ }^{1}$ which applies a nonviolent pedagogical approach in its focus on self-empowerment and creative conflict management. The article discusses the benefits of such an approach and

\footnotetext{
${ }^{1}$ AVP was designed in 1975 in the USA in response to a request from the inmates of Green Haven Prison, New York State who wanted to reduce the physical violence in their prison as well as the recidivism, especially of young prisoners. The 3-day experiential workshop aimed at showing prison inmates how to deal with conflict without resorting to violence. The workshops were well received and prisoners began facilitating their own workshops, some continuing after they were released. Although initially conducted mostly in prisons, the workshops expanded to schools, universities, non-governmental organisations, government corporations, and communities. Run mostly by volunteers, AVP was implemented widely in the USA and spread to other parts of the world. Today, AVP is active in over 50 countries (see http://avp.international/). In South Africa, AVP began in Johannesburg in 1993 and currently there are active groups in Gauteng, Kwa-Zulu Natal, and the Eastern and Western Cape-as well as in Namibia-all of whom regularly conduct workshops in schools for teachers, learners, and lay counsellors and also in community groups and prisons. The authors are certified AVP facilitators and have been conducting AVP workshops in the Eastern Cape since 2005.
} 
conceptually explores how AVP has the potential to provide LO teachers with practical strategies for creative, affirming responses to conflict and violence.

Keywords: decolonisation, experiential learning, life orientation, teacher training, nonviolent pedagogy, life skills

Copyright: (C) 2017 Lamb \& Snoddgrass

This is an open access article distributed under the terms of the Creative Commons Attribution Non-Commercial License, which permits unrestricted non-commercial use, distribution, and reproduction in any medium, provided the original author and source are credited.

\section{Please reference as:}

Lamb, S. \& Snodgrass, L. (2017). A Nonviolent Pedagogical Approach for Life Orientation Teacher Development: The Alternatives to Violence Project. Educational Research for Social Change, 5(2), 115. http://dx.doi.org/10.17159/2221-4070/2017/v6i2a1

\section{Introduction and Background}

In the last decade, numerous studies (Altbeker, 2008, 2011; Cooper \& Foster, 2008; Foster, 2012; Graham, Bruce, \& Perold, 2010; Jewkes, Sikweyiya, Morrell, \& Dunkle, 2010; Ward, 2007; Ward, Dawes, \& van der Merwe, 2012) have explored the causes of South Africa's high rates of violence. Of particular concern is adolescent and youth violence because it is implicated in the rise of gangsterism (Pinnock, 2015; van der Merwe, Dawes, \& Ward, 2012). While unchanging apartheid-based structural inequality, poverty, and unemployment as well as continuing economic, racial, and gender inequality and dysfunctional family dynamics are all implicated, researchers also maintain that South Africa's schools are often breeding grounds for violence because bullying, indiscipline, vandalism, corporal punishment, and gangsterism are prevalent (Ncontsa \& Shumba, 2013; Ward et al., 2012; van der Merwe, 2015). In 2012, 22.2\% of secondary school-goers (just over a million learners) had experienced threats of violence, assaults, robberies, or sexual assaults (including rape) while at school (Makota \& Leoschut, 2016). Schools can also inadvertently encourage socialised acceptance of violence by regarding fights or bullying amongst learners, especially amongst boys, as normal (Graham et al., 2010), and a study conducted in 2008 and updated in 2012 showed an increase in South African school violence and that nearly one in 20 learners had been raped or sexually assaulted at school (Burton \& Leoschut, 2013). Half the children who start school leave before matriculating and 3.4 million young people aged 11 to 24 years are not in education, employment, or training (Pinnock, 2015). In a study highlighting the need for effective school and classroom management strategies to improve school safety, Burton and Leoschut (2013) concluded that classrooms are the most frequent sites for violence occurring in secondary schools, with schoolmates the most common perpetrators. A large percentage of school violence is also perpetuated by teachers who continue to beat learners (Ward, Gould, Kelly, \& Mauff, 2015). Not surprisingly, the consequences of such violence affect the physical, emotional, and academic lives of learners and, importantly, their resistance to delinquent and criminal behaviour (Makota \& Leoschut, 2016).

Given that the foundations for youth violence are laid in early adolescence (Gould, 2015), violence prevention in schools is a critical need. Moffit's (1993) seminal study stressed that violence prevention works best in adolescence and that young people need to be taught how to assert themselves appropriately. 
The challenges for current-day teachers are thus considerable, especially for life orientation (LO) teachers, because one of their primary tasks is to develop learners' social and emotional growth (Department of Education, 2002) and because LO as a school subject has much potential to interrupt long-standing cycles of violence. Introduced as a compulsory subject in the late 1990 s to a democratic South Africa, the aim of LO is to encourage the development of the self-in-society, that is, to promote individual growth as part of the effort to create a democratic society, a productive economy, and an improved quality of life (Department of Education, 2002). LO seeks to prepare learners for successful living in a rapidly transforming society and enable them to contribute to their families and communities (Department of Education, 2002). LO also aspires to raising learners' awareness of their constitutional rights and responsibilities, tolerance for cultural and religious diversity, and how to make informed, morally responsible, and accountable decisions about their health and the environment (Department of Education, 2002).

However, despite this potential to effect meaningful change in the lives of school learners, LO as a school subject in South African schools-with a few notable exceptions-appears to be falling short of its desired outcomes. Studies on LO in South Africa consistently confirm the importance of the subject in the school curriculum, but highlight that LO does not seem to bring about the desired behavioural changes in learners (Christiaans, 2006; Diale, Pillay, \& Fritz, 2014; Jacobs, 2011; Jonck \& Swanepoel, 2015; Mabatha, Magano, \& Sedibe, 2014; Magano, 2011; Matshoba \& Rooth, 2014; Mosia, 2011; Prinsloo, 2007; Rooth, 2005; Theron, 2008; Theron \& Dalzell, 2006; Tlhabane, 2004; van Deventer, $2008,2009)$. Most of these studies call for teacher development programmes that can address the prevailing negative perceptions of LO's low status as a subject in the curriculum. In particular, the studies stress the need for updated personal and professional development programmes for LO teachers and document how LO teachers complain that the Department of Education (DoE) has not prepared them for their daily challenges (Diale et al., 2014; Mabatha et al., 2014; Matshoba \& Rooth, 2014; Rooth, 2005). LO development programmes have been criticised as providing poor quality course material, inadequate after-training support, and being unable to assist teachers to solve practical classroom problems, especially with regards to learner conflict and violence (Christiaans, 2006; Diale et al., 2014; Marumo, 2010; Matshoba \& Rooth, 2014; Mosia, 2011).

While most, if not all, teachers have to deal on a daily basis with learners who are HIV-positive, orphaned, violent, sexually-abused, pregnant, poverty-stricken, or from child-headed households (du Toit, van der Merwe, \& Roussouw, 2007; Snodgrass \& Heleta, 2009), LO teachers have the additional burden of being "suddenly expected to teach a subject they [have] never been trained for" (Diale et al., 2014, p. 84). Their inadequate training, worsened by work overload, often results in "compassion fatigue" (Diale et al., 2014, p. 92) and burnout (Mosia, 2011) which, together with the often negative perceptions of LO by peers and learners, inevitably results in high LO teacher turnover, which exacerbates the problem (Matshoba \& Rooth, 2014).

In addition to needing wider acknowledgement of the challenges of their task, LO teachers need focused professional development that incorporates personal growth opportunities so they can learn how to offer similar self-development opportunities to their learners (Diale et al., 2014; Marumo, 2010; Matshoba \& Rooth, 2014; Mosia, 2011; Sedibe, 2011). Importantly, since LO aims to develop the "self-in-society" (DoE, 2002, pp. 1-2), this article contends that LO teachers must have begun to forge their own "postcolonial identities," that is, to address the question of what it means to be South African post-1994 with the country's transition to a constitutional democracy yet with racism, inequality, and violence still inherent in its structures. Creating a successful postcolonial identity entails claiming the right to speak for oneself, in one's own voice, free of any identity or interpretation imposed by the colonial powers (Bell, 2007). Appropriate self-assertion of this type is key to successful conflict management and violence prevention (Moffit, 1993). 
Pertinent in this regard are the current calls for a national decolonisation of South Africa's social, cultural, and education systems, as witnessed in the \#FeesMustFall movement sweeping across institutions of higher learning, and petitions for the advancement of African scholarship rooted in African contexts (Creary, 2012; Mbembe, 2015; Ngũgĩ wa Thiong'o, 2004). Decolonisation means consciously and actively interrogating hegemonic power differentials and the concomitant psychological effects of embedded structural patterns of violence, power, and control that threaten indigenous ways of being (Sium, Desai, \& Ritskes, 2012). Working towards decolonisation in schools and, by extension, overcoming the brutality of apartheid education in South Africa, does not simplistically mean evoking a narrative of shared humanity premised on the artificial notion of "colourblindness" - the "rainbow nation." The South African schooling system, which has been based on colonial and apartheid education models, cannot be solely concerned with the "decolonisation of the mind" (Ngũgĩ wa Thiong'o, 2004, p. 88), that is, teaching and learning practices of particular nonWestern knowledge systems or curricula. It must also be about conscientising students to the role that social injustice, inequality, and structural violence play in destroying a people's self-esteem, sense of identity, and belief in themselves. Although all teachers participate in these complex conscientisation processes with their learners, because of the LO curriculum, the task is more specifically allocated to the $L O$ teacher.

For these reasons, this article maintains that LO teachers need to be made aware of their own socialisation in violent systems that subjugate, humiliate, and render whole groups of people inferior based on, inter alia, race, sex, age, mental and physical abilities. The empowerment and conscientisation of teachers to "reimagine and rearticulate power, change, and knowledge" (Sium et al., 2012, p. III) and enable learners to do this, is fundamental to the decolonisation of the classroom and the empowerment of learners. Contemporary progressive educational trends therefore highlight the needs of racial, ethnic, gendered, or class minority groups and South African educators are being urged to promote culturally relevant teaching so that diverse cultural values can bring new insights to the learning context (Bozalek \& Boughey, 2012; Ntseane, 2011, 2012; Pillay, 2013; Prinsloo, 2016). In this regard, the potential importance of LO cannot be over emphasised; effective implementation of LO as a school subject could significantly redress past inequities of South Africa (Magano \& Gouws, 2011; Matshoba \& Rooth, 2014), and help learners construct positive identities and responsible relationships with their communities.

This article suggests a practical way of supporting LO teachers in their conscientisation process by proposing that, as part of their development programme, they participate in the 2-day workshops of the AVP process, which provides tools for self-affirmation and creative conflict management. The following sections explain the nonviolent pedagogical nature of the AVP approach, and how this approach is linked to social transformation. The sections also show how, by participating in a personal conscientisation process like AVP and learning more about violence and its prevention, LO teachers could generate meaningful change in learner attitudes and behaviour and, at the same time, achieve greater self-fulfilment and job satisfaction.

\section{Nonviolent Pedagogy and Social Transformation}

As mentioned, the primary aim of the inclusion of $L O$ as a school subject is to encourage the development of selfin-society, that is, to promote individual growth as part of the effort to create a democratic society, a productive economy, and an improved quality of life (DoE, 2002). LO aims to prepare learners for successful living in a rapidly transforming society by developing the social, intellectual, emotional, and physical growth of learners, and enabling them to contribute to their families and communities (DoE, 2002). LO also aspires to raising learners' awareness of their constitutional rights and responsibilities, tolerance for cultural and religious diversity, and how to make informed, morally responsible, and accountable decisions about their health and the environment (DoE, 2002). 
These aims of $L O$ can be aligned to the current global emphasis on social justice education that cautions schools not to perpetuate the social injustices of a dominant-or formerly dominant-society, and stresses how schools can serve as sites for democracy with its ideological, cultural, religious, and social diversity (Adams, Bell, \& Griffin 2007). Social justice education can thus be seen as both a goal and a process and, as a process, is complex, continuous, and often overwhelming because it requires actions "affirming of human agency ... [and] ... working collaboratively to create change" (Bell, 2007, p. 1). Specifically, social justice education aims to help people develop agency and the ability to change oppressive behaviours, both their own and that of their communities (Bell, 2007). Importantly, social justice and diversity are tightly intertwined-without truly valuing diversity, issues of social justice cannot be effectively addressed and, without addressing social justice, we cannot truly value diversity (Bell, 2007).

This juxtapositioning of diversity and social justice is fundamental to a nonviolent pedagogy. As a participatory approach aimed at building trust and appreciating diversity, a nonviolent pedagogy can enhance the transformative processes envisioned by a social justice agenda in two important ways. Firstly, it teaches "difficult knowledge" related to the emotional struggles of unlearning fundamental assumptions, perceptions, and understandings and, in this way, can serve as an antidote to the accumulative effects of violence (Wang, 2010, p. 3). Dismantling oppressive constructs, understanding how they have been created and maintained, and then reconstructing more just alternatives is central to the work of social justice education (Bell, 2007) and key to the work of LO teachers in South Africa. Secondly, a nonviolent pedagogy can uncover hidden sources of conflict, for example, in addressing the unjust social realities of marginalization, conventional social justice education can-sometimes unwittingly-set individuals and groups against one another and promote an "us versus them" mentality (Wang, 2013, p. 494). Because our perceptions of ourselves and others are the root cause of conflict, violence between individuals or social groups, whether ethnic, religious, linguistic, gender, or racial, entails the construction of certain perceptions of one's own group and that of the other (SlocumBradley, 2008). This desire to distance or even erase the other in order to preserve the self is attributed to the dominance mechanism, a mechanism that invariably results in racism, sexism, classism, homophobia, and other forms of prejudice (Wang, 2013).

A nonviolent pedagogy seeks to undo this dominance mechanism by redefining our perception of the other and acknowledging the potential of diversity to contribute to collective well-being (Wang, 2013). It does this primarily by building trust in the classroom, which makes it ideal for the LO teacher whose learners value not "the direct method of teaching ... when the teacher tells them how to conduct themselves . . . but [the] conversation method where there is turn-taking and sequencing of ideas" (Magano, 2011, p. 125). LO learners especially prize the freedom to express their views in a safe space and feel accepted when their points of view are valued by their peers (Magano, 2011).

Thus, a nonviolent pedagogy facilitates the decolonisation of the classroom by creating localised sites for learning democracy where a caring response is foregrounded (Heikkinen, Pihkala, \& Sunnari, 2012). African and feminist perspectives on learning, and expanded conceptions of transformative learning all highlight the importance of caring in effective teaching and learning (John, 2013) and, in an LO classroom especially, teachers are called upon to not only teach content but also to create a humanising atmosphere in their classes (Magano \& Gouws, 2011; Strydom, 2011). The LO teacher thus needs to be open, approachable, and to have empathy and compassion because "the heart is at the centre of all of [ $\mathrm{LO}$ teaching] ... if you don't have the heart, then you're just teaching another academic subject" (Strydom, 2011, p. 75).

The importance of the LO teacher being able to learn and teach key democratic values such as empathy and the motivation and values it engenders (Cooper 2013; Morrell 2010) is thus considerable. The heterogeneity of South Africa's cultural diversity represents rich and varied opportunities for learning 
from the other, but many South Africans of all races are still closed to these prospects. Young people especially are struggling to find their social, ethical, and intellectual bearings in the post-1994 maelstrom (Soudien, 2007) and, for educators to understand why learners respond to the world as they do, they need to take the psychological dimensions of their learners' reality into account. Supporting South African learners to make the shift from an us-versus-them mentality to a more interdependent viewpoint means encouraging them to move from identity politics of static diversity (Wang, 2013), and to renegotiate their historical identities. For LO teachers to be able to do this successfully, they need to have navigated this process themselves - at least to some degree. This is an essential step in the process of developing both self-respect and an appreciation of diversity.

In a country where "social class and wealth determines much of the lived realities of individuals in South Africa ... [and] everyday experiences are overlaid by notions of race, gender, and geographical history" (Sayed, Badroodien, Salmon, \& McDonald, 2016, p. 5), social memory is frequently filled with pain and humiliation. Because of the curricular content of LO, LO teachers are invariably confronted with the enormity of intergenerational and institutionalised oppression. Because collective lived experience is often offered as justification for violence and revenge (Lederach, 2005), LO teachers often find themselves in intense relationships with their learners (Magano, 2011). Assisting young people to deconstruct their memories to renegotiate their identity and "re-story" (Lederach, 2005, pp. 139-140) their personal history, as the LO teacher is often expected to do, needs careful interventions with specific strategies. For LO teachers (especially those from marginalised communities) to be able to do this effectively, they need to first confront their own emotional histories because it is these introspective process that will contribute to social transformation.

Immersion in transformative processes is therefore vital for LO teachers. For LO teachers to be given the opportunity to reflect on, for example, their own socialisation under an oppressive regime or other issues of deep personal significance, is quite different from being trained in LO curriculum content. Studies on LO professional development programmes stress the need for LO teachers to address their own personal development, experiences, and attitudes to life so that they can be better able to help their learners (Diale et al., 2014; Strydom, 2011). In nonviolent pedagogy, inner and outer work are inseparable - to interact nonviolently with others (both friendly and unfriendly), we need to engage in the inner work of transforming our destructive emotions such as hate and fear and make the choice to develop our empathy (Wang, 2013).

Various studies stress the importance of the self-concept of the LO teacher as well as the role that the teacher's classroom facilitation skills, knowledge of alternative instructional strategies, level of commitment, and self-efficacy plays (Diale et al., 2014; Jonck \& Swanepoel 2015; Magano \& Gouws, 2011; Nzeleni, 2015; Sedibe, 2011). Mention is also made of how the attitude of LO teachers, including their attitude to LO as a subject, can influence the social development of learners-especially those from disadvantaged homes-or whether they learn to accept differing viewpoints (Magano \& Gouws, 2011). Supporting LO teachers at regular intervals with self-nurturing workshops such as AVP can help build their self-concept, as well as alleviate their compassion fatigue and frequent burnout (Diale et al., 2014; Magano, 2011), by providing them with opportunities for self-care and reflection.

In AVP workshops, participants are given the opportunity to confront their inner world so that they can make the positive, self-deterministic choices that are fundamental to the decolonisation process, often disrupting generational patterns and contributing to social transformation. Providing LO teachers with a personal experience of nonviolent pedagogy in this way can thus support their development as individuals as well as their ability to bring about social change with communally constructed political visions of nonviolence (Heikkinen et al., 2012). 


\section{The Nonviolent Pedagogical Approach of the AVP Process}

As detailed above, key to a nonviolent pedagogical approach are the affirmation of personal agency, collaboration for change of oppressive behaviour (one's own and others'), and recognition of the value of diversity as well as the unlearning of unconscious prejudice. In AVP, these principles are reflected in its central values: respect for self, caring for others, think before reacting, ask for a nonviolent solution, and expect the best. Overarching these principles is the central AVP notion of a transformative power that we can all access to apply these principles, especially to prevent conflicts from becoming violent.

Studies on LO classrooms emphasise the success of teaching strategies such as discussions, cooperative learning, collaborative problem solving, as well as conversations where learners feel their opinions are valued by the teacher and their peers (Magano, 2011). Modelling such teaching strategies and creating a safe, caring, and values-based environment is the central strength of the AVP process; for many participants, it is their first experience of nonviolent, empathetic communication. Research on empathy shows that giving and receiving empathy are the most fulfilling and gratifying experiences that we can have, and emphasises the relationship of empathy to motivation, values development, and achievement (Cooper, 2013; Goleman, 2009; Morrell, 2010; Rifkin, 2009; Rogers, 1980; Rosenberg, 2015).

The importance of learning through games and play has long been recognised (Axline, 1947; Rousseau, 2003), as has the transformative power of experiential learning (Kolb, 1984; Marsick \& Sauquet, 2014), especially when the activities challenge learners in unconventional ways (Snodgrass \& Blunt, 2009). AVP's practical exercises, games, and role-plays highlight the criticality of perspective taking (SlocumBradley, 2008), and how conflict can be perceived as a destructive or potentially constructive process. Personal agency is emphasised by the power of these perceptual choices, and participants are shown that they are active cocreators of the situations they interpret as conflictual, and how there are always opportunities for transforming conflict in positive directions. The multiple perspectives shared by the group enrich participants' understanding of past conflict events as well as potential future situations (Halfman \& Couzij, 2009). Thus, by participating in these AVP processes, LO teachers can increase their "conflict fluency" (LeBaron \& Pillay, 2006, p. 12) and gain practical skills for managing conflict in their classrooms.

The AVP process is nondirective in that it is not premised on moralistic perspectives of "right" or "wrong." Workshops allow participants to reflect on their personal histories and reconsider their values by providing the conditions for unlearning and changes in perspective taking (Hackland, 2007). This participant-centred focus is a sharing process where knowledge is actively coconstructed, and participants are encouraged to introspect and develop creative ways of resolving conflicts. Such communal involvement in coconstructed knowledge acquisition is an essential feature of Afrocentric learning, which negates the existence of absolute knowledge and highlights communal knowledge construction (Ntseane, 2011). Also known in conflict management as the "elicitive approach" (Lederach, 1995, p. 62), coconstruction builds on the knowledge available in a diverse workshop setting rather than depending on the trainer as expert (as is usually done in the Eurocentric/colonial approach), thus recognising the knowledge of the participants as fundamental to the learning process.

In opening up the space for participants to express their feelings, any habitual language of criticism or moralistic judgments is highlighted and participants are shown how to understand the link between accessing their feelings and needs and communicating nonviolently. Although this is essentially an emotional process, AVP is not therapy and these inner re-storying processes occur spontaneously in the shared group experience. The games bring the healing of shared laughter, which is important to the re-storying process: 
Reconciliation ... the effort to repair the brokenness of relationships and life ... appears as a very serious business. Ironically the pathway to healing may not lie with becoming more serious [and] ... may explain [why] people of so many geographies of violence have developed such an extraordinary sense of humour and playfulness. (Lederach, 2005, $p$. 160)

Healing laughter is also generated in the role-plays where participants enact conflict situations and, as a group, consider the options available in dealing with conflict. As in life, these role-plays are spontaneous and each group decides on a conflict scenario, constructs the plot, and whatever emerges as an outcome becomes the basis for a lesson in managing conflict. In this way, responding to the participants' expressed needs, the AVP facilitators (two or three, for increased diversity) collaborate to create a deep learning environment.

Studies on the effectiveness of AVP-including those by John $(2013,2015)$, Novek (2011), and Shuford $(2009,2013)$, as well as a number of other reports from countries around the world and archived on the AVP-USA website (https://avpusa.org/resources-pub/avp-research-4/)-reveal encouraging, mostly positive findings that attest to the power of this communal knowledge construction. In South Africa, AVP groups in Gauteng, KwaZulu-Natal as well as the Eastern and Western Cape regularly conduct AVP workshops in schools, prisons, and communities and studies exploring their effectiveness (de Villiers Graaff, 2005; Hackland, 2007; John, 2013, 2015; Lamb-du Plessis 2012; Roper, 2005) have yielded similarly positive results. Several of these studies explain how workshop participants frequently adopt a new perspective to previously unquestioned worldviews. For example, Sloane (2002, p. 21) showed how the shift from antisocial to pro-social behaviours does not develop linearly, but reaches a "tipping point" when a certain level of affective trust and social coherence is reached in the group. He saw this trust as the basis upon which other pro-social skills are developed, including self-esteem and empathy, and attributed this development to the effective creation of conditions in which changes of perception can occur, especially with regard to conflict. These conditions appear related to how AVP addresses the important psychological need for connection with others and that when participants experience this sense of connection, they view themselves and others differently. Studies have shown that this change is not temporary but-to a significant degree-is sustained (Lamb-du Plessis, 2012; Miller \& Shuford, 2005; Novek, 2011; Shuford, 2013).

\section{The AVP Workshop: Structure, Content, and Outcomes}

The AVP process is based on four central themes: affirmation, communication, cooperation, and community building, which align with the LO topics of social and environmental responsibility, democracy and human rights, and especially, the development of self-in-society with its aim of "the promotion of individual growth and well-being in a rapidly transforming society" (DoE, 2002, p. 3). The workshops are graded into three levels: the basic workshop, the advanced, and the facilitator workshop, and the LO teacher is encouraged to participate in all three. The duration of each workshop is two days (which can be adjusted into 1- or 2-hour, weekly sessions), participation is limited to 25 participants and, as mentioned, each workshop has two to three facilitators.

Table 1 details the format of a standard AVP basic workshop showing the activities, issues explored, and outcomes. 
Table 1: AVP workshop structure (adapted from Connors, 2012)

\begin{tabular}{|c|c|c|c|}
\hline \multicolumn{4}{|c|}{ Standard format of an AVP basic workshop } \\
\hline Activity & Methodology & Issues Explored & Outcomes \\
\hline \multirow{6}{*}{$\begin{array}{l}\text { Session } 1 \\
\text { Affirmation and } \\
\text { Listening }\end{array}$} & Introductions. & $\begin{array}{l}\text { Creating a safe space by } \\
\text { modelling authenticity. }\end{array}$ & $\begin{array}{l}\text { Begins the process of building } \\
\text { self-esteem and self-awareness } \\
\text { as well as our impact on others. }\end{array}$ \\
\hline & $\begin{array}{l}\text { workshop boundaries e.g., } \\
\text { confidentiality or volunteering } \\
\text { only yourself. }\end{array}$ & $\begin{array}{l}\text { How we feel when we are } \\
\text { affirmed by others publicly, }\end{array}$ & $\begin{array}{l}\text { Awareness of what is needed to } \\
\text { successfully participate in a }\end{array}$ \\
\hline & & Participating in a group. & cooperative group process. \\
\hline & $\begin{array}{l}\text { Affirmatory name games-ice } \\
\text { breakers that create playful } \\
\text { but positive identities for } \\
\text { participants. }\end{array}$ & $\begin{array}{l}\text { Exploring causes and effects of } \\
\text { violence. }\end{array}$ & $\begin{array}{l}\text { Ability to list various forms of } \\
\text { violence, both overt and covert, } \\
\text { and recognition of how we } \\
\text { direct violence at ourselves. }\end{array}$ \\
\hline & $\begin{array}{l}\text { Exercises and brainstorms. } \\
\text { Although full participation is } \\
\text { encouraged, no activity is } \\
\text { compulsory. }\end{array}$ & & $\begin{array}{l}\text { Awareness of the link between } \\
\text { self-compassion and empathy. }\end{array}$ \\
\hline & $\begin{array}{l}\text { Processing and discussion- } \\
\text { facilitated group sharing. }\end{array}$ & & \\
\hline \multirow[t]{3}{*}{ Communication } & $\begin{array}{l}\text { Communication exercise that } \\
\text { continues building self- } \\
\text { esteem. }\end{array}$ & $\begin{array}{l}\text { Elements of effective } \\
\text { communication including active } \\
\text { listening. }\end{array}$ & $\begin{array}{l}\text { Demonstration of effective } \\
\text { communication. Awareness of } \\
\text { the importance of listening and } \\
\text { its link to empathy. }\end{array}$ \\
\hline & $\begin{array}{l}\text { Talking/listening exercise in } \\
\text { pairs. Exercise on exploring } \\
\text { conflict e.g., brainstorming }\end{array}$ & $\begin{array}{l}\text { The role of affirmation in building } \\
\text { self-esteem. }\end{array}$ & $\begin{array}{l}\text { Demonstration of growing self- } \\
\text { esteem and awareness. }\end{array}$ \\
\hline & $\begin{array}{l}\text { the "roots and fruits" of } \\
\text { violence. } \\
\text { Processing and discussion. }\end{array}$ & $\begin{array}{l}\text { Individual and group practice of } \\
\text { resolving conflict-small group } \\
\text { sharing of conflict experiences. }\end{array}$ & $\begin{array}{l}\text { Ability to outline the conflict } \\
\text { resolution and transformation } \\
\text { process. }\end{array}$ \\
\hline \multirow{3}{*}{$\begin{array}{l}\text { Session } 3 \\
\text { Cooperation and } \\
\text { Trust Building }\end{array}$} & $\begin{array}{l}\text { Cooperative construction } \\
\text { exercise done in small groups } \\
\text { without talking. }\end{array}$ & $\begin{array}{l}\text { The role of communication in } \\
\text { cooperation. }\end{array}$ & $\begin{array}{l}\text { Ability to describe the role of } \\
\text { communication in cooperation. }\end{array}$ \\
\hline & Trust exercise. & $\begin{array}{l}\text { How trust is built and broken- } \\
\text { small group exercise in giving and } \\
\text { receiving empathy. }\end{array}$ & $\begin{array}{l}\text { Ability to identify components } \\
\text { of trustworthy relationships. }\end{array}$ \\
\hline & Processing and discussion. & & \\
\hline \multirow{3}{*}{$\begin{array}{l}\text { Session } 4 \\
\text { Transforming } \\
\text { Conflicts and } \\
\text { Creative Conflict } \\
\text { Management }\end{array}$} & $\begin{array}{l}\text { Power exercise-reflection on } \\
\text { AVP core principles: respect } \\
\text { for self, caring for others, }\end{array}$ & $\begin{array}{l}\text { The role of perceptual choice in } \\
\text { transforming conflicts. }\end{array}$ & $\begin{array}{l}\text { Demonstration of how to work } \\
\text { with power. }\end{array}$ \\
\hline & $\begin{array}{l}\text { think before reacting, ask for } \\
\text { a nonviolent solution, expect } \\
\text { the best. }\end{array}$ & $\begin{array}{l}\text { Group decision on issues to be } \\
\text { explored in role-plays. }\end{array}$ & $\begin{array}{l}\text { Consensus (agreement by } \\
\text { discussion, with everyone's } \\
\text { views taken into account) on } \\
\text { role-play selection. }\end{array}$ \\
\hline & $\begin{array}{l}\text { Role-play introduction, } \\
\text { processing and discussion. }\end{array}$ & & \\
\hline
\end{tabular}




\begin{tabular}{|c|c|c|c|}
\hline \multirow{3}{*}{$\begin{array}{l}\text { Session } 5 \\
\text { Practical Conflict } \\
\text { Transformation }\end{array}$} & $\begin{array}{l}\text { Role-plays: implementing the } \\
\text { practical skills learned in the } \\
\text { previous sessions. }\end{array}$ & $\begin{array}{l}\text { Group's choice of topic explored } \\
\text { in depth }\end{array}$ & $\begin{array}{l}\text { Demonstration of the learnings } \\
\text { of the workshop in the role- } \\
\text { plays. }\end{array}$ \\
\hline & $\begin{array}{l}\text { Debriefing, processing, and } \\
\text { discussion. }\end{array}$ & & $\begin{array}{l}\text { Application of the AVP principles } \\
\text { in conflict scenarios relevant to } \\
\text { participants. }\end{array}$ \\
\hline & & & $\begin{array}{l}\text { Awareness of alternative ways } \\
\text { of dealing with conflict. }\end{array}$ \\
\hline \multirow{4}{*}{$\begin{array}{l}\text { Session } 6 \\
\text { Affirmation and } \\
\text { Closing }\end{array}$} & Role-play revisited. & Outstanding issues raised during & Demonstration of self- \\
\hline & $\begin{array}{l}\text { Participant posters affirming } \\
\text { each other. }\end{array}$ & $\begin{array}{l}\text { the role-plays. } \\
\text { Affirmation. }\end{array}$ & $\begin{array}{l}\text { empowerment in deallng with } \\
\text { conflict and affirming each } \\
\text { other. }\end{array}$ \\
\hline & $\begin{array}{l}\text { Participants' overall } \\
\text { evaluation of the workshop. } \\
\text { Processing and discussion. }\end{array}$ & $\begin{array}{l}\text { Participant evaluation of } \\
\text { workshop. }\end{array}$ & $\begin{array}{l}\text { Expression of the value of } \\
\text { participants' opinions of the } \\
\text { workshop. }\end{array}$ \\
\hline & $\begin{array}{l}\text { Graduation led by } \\
\text { participants. }\end{array}$ & & $\begin{array}{l}\text { Demonstration of participant } \\
\text { validation by receiving } \\
\text { affirmation posters from other } \\
\text { participants and codirecting the } \\
\text { graduation. }\end{array}$ \\
\hline
\end{tabular}

The core of the workshop is divided into four main sessions, each session focussing on a theme. All the activities are aligned to the theme and follow each other sequentially in increasing complexity. The process begins by positively affirming the participants and creating a space where they can reveal vulnerabilities, and then facilitates communication, cooperation, and creative conflict transformation exercises in pairs and small groups. Social workers or psychologists are included in the facilitator team to ensure support if revealing vulnerabilities cause discomfort.

The advanced workshop has an increased focus on community building and, in particular, on participants' individual goals. Once they have clarified personal goals, participants work to integrate their goals with the group goals by choosing two or three topics as the focus for the second section of the workshop. This goal integration is done through a process of consensus and the experience of making a collective decision, which values individual viewpoints, is key to increasing participants' awareness of inclusivity and teamwork. Participants are taken through specific exercises aimed at deepening their understanding of the topic and clarifying problem areas. AVP training is thus presented in differing levels of complexity from basic to advanced. Once both the basic and advanced workshops have been successfully completed, the facilitator workshop affords the opportunity to be trained as an AVP facilitator. Although it would be ideal for LO teachers to become fully-fledged AVP facilitators, participating in even one basic workshop could be a valuable and useful experience for them.

To summarise, an AVP workshop can provide a safe space where participants are able to examine their unconscious, often destructive, assumptions and are given tools for resolving conflicts through consensus and compromise as well as communication skills that can de-escalate potentially violent and dangerous confrontations (Novek, 2011). These skills are critical for LO teachers as is AVP's philosophy of nonviolent pedagogy, which collapses the traditional teacher-learner power relationships and could make the classroom a more democratic and empowering space. Importantly, the personally relevant processes of an AVP workshop are quite different from the largely generic, content-burdened workshops currently offered to LO teachers, which often leave them confused and frustrated (Diale et al., 2014; Mosia, 2011). In contrast to current LO teaching methodologies which 
mostly employ transmission teaching, with minimal use of group and experiential methods (Prinsloo, 2007), AVP's participatory processes model a nonviolent, democratic pedagogy through learnercentred experiential learning that LO teachers could replicate in their classrooms.

\section{Conclusion}

The LO teacher has the potential to be an important catalyst for critical social change that begins in the nonviolent classroom. A nonviolent pedagogy can help undo the legacy of racial, gender, class, and other historical social violence (Wang, 2010) and build robust identities, self-knowledge, and agency that can assist teachers and their learners to contribute to South Africa's decolonisation project.

AVP processes that embody such an approach can comprehensively support LO teachers by providing them with opportunities to reflect on their socialisation and offers strategies for the development of life skills, assertiveness, and conflict transformation in their learners, which take into account learners' actual behaviour as well as historical, social, and environmental determinants. However, even more important, is that LO teachers can learn how to create democratic and humanising spaces that validate learners' experiences and viewpoints. LO teachers participating in AVP workshops with a view to replicating its strategies could be supported in this process by local South African AVP groups, and encouraged to participate in AVP's national and global network.

\section{References}

Adams, M., Bell, L. A., \& Griffin, P. (2007). Teaching for diversity and social justice. New York, USA: Routledge.

Altbeker, A. (2008). Adding insult to injury: How exclusion and inequality drive South Africa's problem of violence (Report on Component 4 of a study conducted by Centre for the Study of Violence and Reconciliation for the Justice, Crime Prevention and Security Cluster). Retrieved from https://www.csvr.org.za/docs/study/4.Book SocioEconomic 2003 2009.pdf

Altbeker, A. (2011, October 28). Why are we such a violent people? Daily Maverick. Retrieved from https://www.dailymaverick.co.za/opinionista/2011-10-28-why-are-we-such-a-violentpeople/\#.WSB6lj7ljQE.email

Axline, V. M. (1947). Play therapy. New York, USA: Ballantine.

Bell, L. A. (2007). Theoretical foundations for social justice education. In M. Adams, L. A. Bell, \& P. Griffin (Eds.), Teaching for diversity and social justice (pp. 1-14). New York, USA: Routledge.

Bozalek, V., \& Boughey, C. (2012). (Mis)framing higher education in South Africa. Social Policy \& Administration, 46(6), 688-703.

Burton, P., \& Leoschut, L. (2013). School violence in South Africa: Results of the 2012 national school violence study (Monograph series, No. 12). Cape Town, South Africa: Centre for Justice and Crime Prevention. Retrieved from http://www.cjcp.org.za/uploads/2/7/8/4/27845461/monograph12school-violence-in-south africa.pdf

Christiaans, D. J. (2006). Empowering teachers to implement the Life Orientation learning area in the Senior Phase of the General Education and Training Band (Unpublished master's thesis). University of Stellenbosch, South Africa.

Connors, J. (2012). Alternatives to Violence Project (Manual Basic Course). Johannesburg, South Africa: Phaphama Initiatives.

Cooper, B. (2013). Empathy in education: Engagement, values and achievement. London, UK: Continuum. 
Cooper, A., \& Foster, D. (2008). Democracy's children? Masculinities of coloured adolescents awaiting trial in post-apartheid Cape Town, South Africa. Thymos: Journal of Boyhood Studies, 2(1), 3-25.

Creary, N. (Ed.). (2012). African intellectuals and decolonization (Research in International Studies, Africa Series No. 90). Athens, USA: Ohio University Press.

De Villiers Graaff, K. (2005). A study of conflict resolution workshops in Western Cape prisons (Unpublished honours treatise). University of Cape Town, South Africa.

Department of Education (DoE). (2002). Revised national curriculum statement Grades R-9 (schools): Life orientation. Pretoria, South Africa: DoE.

Diale, B., Pillay, J., \& Fritz, E. (2014). Dynamics in the personal and professional development of lifeorientation teachers in South Africa, Gauteng Province. Journal of Social Sciences, 38(1), 83-93.

Du Toit, D., van der Merwe, N., \& Rossouw, J. P. (2007). Return of physical education to the curriculum: Problems and challenges facing schools in South African communities. African Journal for Physical, Health Education, Recreation and Dance, 13(3), 241-253.

Foster, D. (2012). Gender, class, 'race' and violence. In C. L. Ward, A. Dawes, \& A. van der Merwe (Eds.), Youth violence: Sources and solutions in South Africa (pp. 23-52). Cape Town, South Africa: UCT Press.

Galtung, J. (1990). Cultural violence. Journal of Peace Research, 27, 38-302.

Goleman, D. (2009). Emotional intelligence: Why it can matter more than IQ. London, UK: Bloomsbury.

Gould, C. (2015). Beaten bad: The life stories of violent offenders (Monograph 192). Pretoria, South Africa: Institute for Security Studies.

Graham, B., Bruce, D., \& Perold, H. (2010). Ending the age of the marginal majority: An exploration of strategies to overcome youth exclusion, vulnerability and violence in southern Africa. Johannesburg, South Africa: Southern Africa Trust.

Hackland, T. (2007). External evaluation: Phaphama Initiatives' Alternatives to Violence Project at Leeuwkop Correctional Centre. Johannesburg, South Africa: Inkanyesi Initiative.

Halfman, I., \& Couzij, T. (2009). Collaboratively interpreting text: The workshop's impact is reflected in conflict stories (Additional evaluation report 2008-2009). Amsterdam, Netherlands: DiversityJoy.

Heikkinen, M., Pihkala, S., \& Sunnari, V. (2012). A European e-learning program on gendered and sexual violence: Developing a feminist pedagogy of non-violence. In S. Collingwood, A. E. Quinta, \& C. J. Smith (Eds.), Feminist cyberspaces: Pedagogies in transition (pp. 176-201). Newcastle-upon-Tyne, UK: Cambridge Scholars.

Jacobs, A. (2011). Life orientation as experienced by learners: A qualitative study in North-West Province. South African Journal of Education, 31(2), 212-223.

Jewkes, R., Sikweyiya, Y., Morrell, R., \& Dunkle, K. (2010). Why, when and how men rape: Understanding rape perpetration in South Africa. South African Crime Quarterly, 34, 23-31.

John, V. (2013). Transforming power and transformative learning in peace educator development. Journal of Social Sciences, 37(1), 81-91.

John, V. M. (2015). Up close and personal: Theorising care work in adult education. Research Papers in Education, 31(3), 337-351. doi:10.1080/02671522.2015.1073772

Jonck, P., \& Swanepoel, E. (2015). Exploring the perceived role of life orientation teachers with reference to career guidance provided to Grade 10 learners in the Free State, South Africa. International Journal of Humanities Social Sciences and Education, 2(5), 229-239. 
Kolb, D. A. (1984). Experiential learning: Experience as the source of learning and development. Englewood Cliffs, USA: Prentice Hall.

Lamb-du Plessis, S. (2012). Exploring the conflict narratives of youth at risk (Unpublished master's thesis). Nelson Mandela Metropolitan University, South Africa.

LeBaron, M., \& Pillay, V. (2006). Conflict across cultures. Boston, USA: Intercultural Press.

Lederach, J. P. (1995). Preparing for peace: Conflict transformation across cultures. New York, USA: Syracuse University Press.

Lederach, J. P. (2005). The moral imagination: The art and soul of building peace. Oxford, UK: Oxford University Press.

Mabatha, T. M., Magano, M. D., \& Sedibe, M. (2014). Challenges experienced by life orientation teachers with regard to Grade 9 learners on learner bullying in Gauteng West. Anthropologist, 17(1), 233-241.

Magano, M. D. (2011). The new kind of teacher to handle the new subject, life orientation, in a township high school in South Africa. Journal of Social Sciences, 28(2), 119-127.

Magano, M. D., \& Gouws, F. E. (2011). Exploring the relationship between the social self-concepts of black South African adolescents and a disadvantaged home environment: A life orientation perspective. Journal of Social Sciences, 28(3), 161-167.

Makota, G., \& Leoschut, L. (2016). The National School Safety Framework: A framework for preventing violence in South African schools. African Safety Promotion, 14(2), 18-23.

Marsick, V. J., \& Sauquet, A. (2014). Learning through reflection. In P. Coleman, M. Deutsch, P. T. Coleman, \& E. Marcus (Eds.), The handbook of conflict resolution: Theory and practice (4th ed., pp. 499-521). San Francisco, USA: Jossey-Bass.

Marumo, L. P. (2010). The impact of in-service educator professional development programmes on Grade 10 life orientation educators (Unpublished master's thesis). North-West University, South Africa.

Matshoba, H., \& Rooth, E. (2014). Living up to expectations? A comparative investigation of Life Orientation in the National Senior Certificate and the National Certificate (Vocational). Pretoria, South Africa: Umalusi, Council for Quality Assurance in General and Further Education and Training.

Mbembe, A. (2015). Decolonizing knowledge and the question of the archive. Retrieved from http://wiser.wits.ac.za/system/files/Achille\%20Mbembe\%20\%20Decolonizing\%20Knowledge\%20and\%20the\%20Question\%20of\%20the\%20Archive.pdf

Miller, L. M., \& Shuford, J. A. (2005). The Alternatives to Violence project in Delaware: A three-year cumulative recidivism study. Retrieved from https://avpusa.org/resources-fac/avp-research/

Moffit, T. E. (1993). Adolescence-limited and life-course-persistent antisocial behavior: A developmental taxonomy. Psychological Review, 100(4), 674-701.

Morrell, M. (2010). Empathy and democracy: Feeling, thinking and deliberation. Pennyslvania, USA: Pennyslvania State University Press.

Mosia, D. (2011). How secondary-school teachers understand, respond to and implement life orientation (Unpublished doctoral dissertation). University of Pretoria, South Africa.

Ncontsa, V. N., \& Shumba, A. (2013). The nature, causes and effects of school violence in South African high schools. South African Journal of Education, 33(3). Retrieved from http://www.scielo.org.za/scielo.php?script=sci arttext\&pid=S0256-01002013000300013

Ngũgĩ wa Thiong'o. (2004). Decolonizing the mind: The politics of language in African literature. Nairobi, Kenya: East African Educational. 
Novek, E. (2011). The Alternatives to Violence Project's work for peace behind bars. Peace Review, 23(3), 335-341.

Ntseane, P. G. (2011). Culturally sensitive transformational learning incorporating the Afrocentric paradigm and African feminism. Adult Education Quarterly, 61(4), 307-323.

Ntseane, G. P. (2012). Transformative learning theory: A perspective from Africa. In E. W. Taylor, P. Cranton, \& Associates (Eds.), The handbook of transformative learning: Theory, research, and practice (pp. 274-288). San Francisco, USA: Jossey-Bass.

Nzeleni, L. P. (2015). Provision of guidance and counselling services in the schools in the Transkei subregion of the Eastern Cape (Unpublished master's thesis). University of South Africa, South Africa.

Pillay, S. (2013, April 5). Decolonising the Humanities. Mail \& Guardian. Retrieved from https://mg.co.za/article/2013-04-05-decolonising-the-humanities

Pinnock, D. (2015). Gang Town. Cape Town, South Africa: NB.

Prinsloo, E. (2007). Implementation of life orientation programmes in the new curriculum in South Africa: Perceptions of principals and life orientation teachers. South African Journal of Education, 27(1), 155-170.

Prinsloo, E. (2016). The role of the humanities in decolonizing the academy. Arts \& Humanities in Higher Education, 15(1), 164-168.

Rifkin, J. (2009). The empathic civilisation: The race to global consciousness in a world in crisis. New York, USA: Penguin.

Rooth, E. (2005). An investigation of the status and practice of life orientation in South African schools in two provinces (Unpublished doctoral dissertation). University of the Western Cape, South Africa.

Rogers, C. (1980). A way of being. New York, USA: Houghton Mifflin Harcourt.

Roper, M. (2005). A review of the Integrated Youth Offender Programme piloted in Boksburg Juvenile Correctional Centre with the "Inkanyezi yentathakusa." IYOP External Review. Retrieved from http://www.phaphama.org/downloads/files/INTEGRATED\%20YOUTH\%20OFFENDER\%20PROGRA MME\%20final\%20edited\%20M.pdf

Rosenberg, M. (2015). Nonviolent communication: A language of life, life-changing tools for healthy relationships. Encinitas, USA: Puddledancer Press.

Rousseau, J. (2003). Emile: Or treatise on education (W. H. Payne, Trans.). New York, USA: Prometheus Books.

Sayed, Y., Badroodien, A., Salmon, T., \& McDonald, Z. (2016). Social cohesion and initial teacher education in South Africa. Educational Research for Social Change, 5(1), 54-69.

Sedibe, M. (2011). Cultural diversity in a teacher training life orientation programme at a higher education institution (HEI), South Africa. Journal of Social Sciences, 29(2), 171-176.

Shuford, J. A. (2009, January 1). AVP: An instrument of peace. Friends Journal. Retrieved from https://www.friendsjournal.org/avp-instrument-peace/

Shuford, J. A. (2013). AVP and trauma (Report for AVP-USA). Retrieved from https://avpwiki.wikispaces.com/file/view/AVP\%20and\%20Trauma-JShufordUS2013.pdf/429464094/AVP\%20and\%20Trauma-JShufordUS-2013.pdf

Sium, A., Desai, C., \& Ritskes, E. (2012). Towards the 'tangible unknown': Decolonization and the Indigenous future. Indigeneity, Education \& Society, 1(1): I-XIII.

Sloane, S. (2002). A study of the effectiveness of the alternatives to violence project workshops in a prison system (Unpublished doctoral dissertation). Case Western University, USA. 
Slocum-Bradley, N. (2008). Promoting conflict or peace through identity. Hampshire, UK: Ashgate.

Snodgrass, L., \& Blunt, R. J. S. (2009). The value of play for conflict management: A case study. South African Journal of Education, 29, 53-67.

Snodgrass, L., \& Heleta, S. (2009). Teachers' experiences of conflict and violence in township schools. Commonwealth Youth and Development Journal, 7(2), 41-54.

Soudien, C. (2007). Youth identity in contemporary South Africa: Race, culture and schooling. Cape Town, South Africa: New Africa Education.

Strydom, V. Z. (2011). The support needs of life orientation teachers in the Further Education and Training Band (Unpublished master's thesis). University of Stellenbosch, South Africa.

Theron, L. C. (2008). The Batsha-life orientation study: An appraisal by Grade 9 learners living in townships. Education as Change, 12(1), 45-65.

Theron, L. C., \& Dalzell, C. (2006). The specific life orientation needs of Grade 9 learners in the Vaal Triangle region. South African Journal of Education, 26(3), 397-412.

Thabane, E. M. (2004). The training needs of life orientation educators in the Mabopane District (Unpublished master's thesis). University of South Africa, South Africa.

Van der Merwe, A., Dawes, A., \& Ward, C. L. (2012). The development of youth violence: An ecological understanding. In C. L. Ward, A. van der Merwe, \& A. Dawes (Eds.), Youth violence: Sources and solutions in South Africa (pp. 53-92). Cape Town, South Africa: UCT Press.

Van der Merwe, M. (2015, July 16). Knife's edge: How dangerous are South African schools? Daily Maverick. Retrieved from: https://www.dailymaverick.co.za/article/2015-07-16-knifes-edge-howdangerous-are-south-africas-schools/\#.WSObAut96G4

Van Deventer, K. J. (2008). Perceptions of life orientation teachers regarding the implementation of the learning area in Grades 8 and 9: A survey in selected Cape High Schools. South African Journal for Research in Sport, Physical Education and Recreation, 30(2), 131-146.

Van Deventer, K. J. (2009). Perspectives of teachers on the implementation of life orientation in Grades R-11 from selected Western Cape schools. South African Journal of Education, 29, 127-145.

Wang, H. (2010). A zero space of nonviolence. Journal of Curriculum Theorizing, 26(1), 1-8.

Wang, H. (2013). A nonviolent approach to social justice education. Educational Studies: A Journal of the American Studies Association, 49(6), 485-503.

Ward, C. L. (2007). Young people's violent behaviour: Social learning in context. In P. Burton (Ed.), Someone stole my smile: An exploration into the causes of youth violence in South Africa (pp. 936). Cape Town, South Africa: Centre for Justice and Crime Prevention.

Ward, C. L., Dawes, A., \& van der Merwe, A. (2012). Youth Violence: Sources and solutions in South Africa. Cape Town, South Africa: UCT Press.

Ward, C. L., Gould, C., Kelly, J., \& Mauff, K. (2015). Spare the rod and save the child: Assessing the impact of parenting on child behaviour and mental health. South African Crime Quarterly, 51. Retrieved from https://www.ajol.info/index.php/sacq/article/view/114947 